\title{
The estimation of an anthropogenic depth boundary using the magnetic susceptibility method in Kogi State, North-Central Nigeria
}

\author{
Solomon Sunday Jatto ${ }^{1}$, Kizito O. Musa², Usikalu R. Mojisola ${ }^{3}$ \\ ${ }^{1}$ National Space Research and Development Agency, Space Environment Research Laboratory; Airport Road, Abuja, Nigeria; \\ e-mail: jattosolomon@gmail.com; ORCID ID: 0000-0001-5484-3108 \\ ${ }^{2}$ Federal University, Department of Geology; Lokoja, Nigeria; e-mail: kizito.musa@yahoo.com \\ ${ }^{3}$ Covenant University; Ota, Nigeria; e-mail:moji.usikalu@convenantuniversity.edu.ng
}

(C) 2020 Authors. This is an open access publication, which can be used, distributed and reproduced in any medium according to the Creative Commons CC-BY 4.0 License requiring that the original work has been properly cited.

Received: 19 December 2019; accepted: 30 March 2020; first published online: 8 May 2020

\begin{abstract}
Magnetic susceptibility measurements remain one of the most reliable methods used to investigate the pollution of both surface and subsurface soil from metallic anthropogenic sources. Most of the geological rocks within the study area increase the susceptibility of the soil; however, knowing the natural background susceptibility of the parent rocks will give an idea of the anthropogenic influence on the susceptibility of the soil. This study was carried out in Kogi State, North Central Nigeria, with the aim of determining the depth of the boundary between the anthropogenic influences on soil magnetic susceptibility from those of a lithogenic origin. Magnetic susceptibility measurements were carried out on 1,760 soil samples, collected from 220 soil profiles at a depth of $80.0 \mathrm{~cm}$ and at intervals of $10.0 \mathrm{~cm}$. From the spatial distribution of magnetic susceptibility maps at different depths, the boundary between the basement complex and the sedimentary basin was clearly demarcated. The result further shows the highest magnetic susceptibility values of 350-650 $\times 10^{-5} \mathrm{SI}$, which dominates the surface soil to a depth of $40.0 \mathrm{~cm}$. At the depth of $40-50 \mathrm{~cm}$, the result indicates the combination of a natural anthropogenic influence on soil magnetic susceptibility with an average of $250 \times 10^{-5} \mathrm{SI}$. Furthermore, no evidence of layering along the depth sections was observed, suggesting that the soil profiles indicate areas mainly covered by anthropogenically influenced susceptibility, which were localized and restricted to commercial places within the state. This study reveals that the average depth of soil affected by anthropogenic pollutants is between $40-50 \mathrm{~cm}$ in commercial places and $20-30 \mathrm{~cm}$ in other places with less commercial activities.
\end{abstract}

Keywords: magnetic susceptibility, anthropogenic, pollutants, soil profiles, Central Nigeria

\section{INTRODUCTION}

The presence of ferrimagnetic minerals in soil samples has an influence on magnetic susceptibility, and this is a valuable and fast method of monitoring soil pollution in different areas (D'Emilio et al. 2007, Jordanova et al. 2008, Zawadzki et al. 2012, Jatto et al. 2016). Studies by Georgeaud et al. (1997), suggest that magnetic minerals present in soil might have come about as a result of the weathering of the parent rocks (lithogenic source), anthropogenic activities or through pedogenic processes. Generally, the magnetic susceptibility of the parent rocks within a given study area is found to be less significant in comparison with anthropogenic input on soil. Several studies have indicated that the enhancement of magnetic susceptibility around industrial, 
transportation and commercial areas may be due to the deposition of anthropogenic pollutants. This is because of the existing relationship between magnetic susceptibility and the concentration of heavy metals in the soil (Georgeaud et al. 1997, Petrovský \& Elwood 1999, Knab et al. 2001, Chaparro et al. 2006, Kim et al. 2007). Magnetic susceptibility has been used in different places to estimate the depth between anthropogenic and lithogenic influenced soil magnetic susceptibility (Dearing et al. 1996, Kapička et al. 2001, Boyko et al. 2004, Magiera et al. 2006, Lu \& Bai 2008, Sarris et al. 2009, Zananiri et al. 2010, Jatto et al. 2016). The simplicity of applying the magnetic susceptibility method, combined with its rapid results, makes it easier to estimate the thickness of soil affected and enriched by technogenic magnetic particles in a given area. Despite these benefits, only a few studies have been performed in Nigeria in recent decades (Kanu et al. 2013, Jatto et al. 2016).
The aim of this study is to determine the thickness of the anthropogenic pollutants deposited within the soil and to estimate the boundary between the anthropogenic influenced susceptibility with lithogenic influenced susceptibility of soil in Kogi State, North-Central Nigeria.

\section{THE STUDY AREA}

Kogi State is located in North-Central Nigeria and between a latitude of $7^{\circ} 30^{\prime} \mathrm{N}$ and $7^{\circ} 50^{\prime} \mathrm{N}$ and longitude $6^{\circ} 42^{\prime} \mathrm{E}$ and $6^{\circ} 70^{\prime} \mathrm{E}$. It covers an area of $29,833 \mathrm{~km}^{2}$. It is popularly known as the Confluence State because it serves as the confluence of Niger River and Benue River at the state capital of Lokoja, which was the first administrative capital of modern Nigeria. Kogi state consists of twenty-one (21) Local Government Areas (Fig. 1) and it is the only state which shares a boundary with ten other states, thus serving as a link route to many other parts of the country.

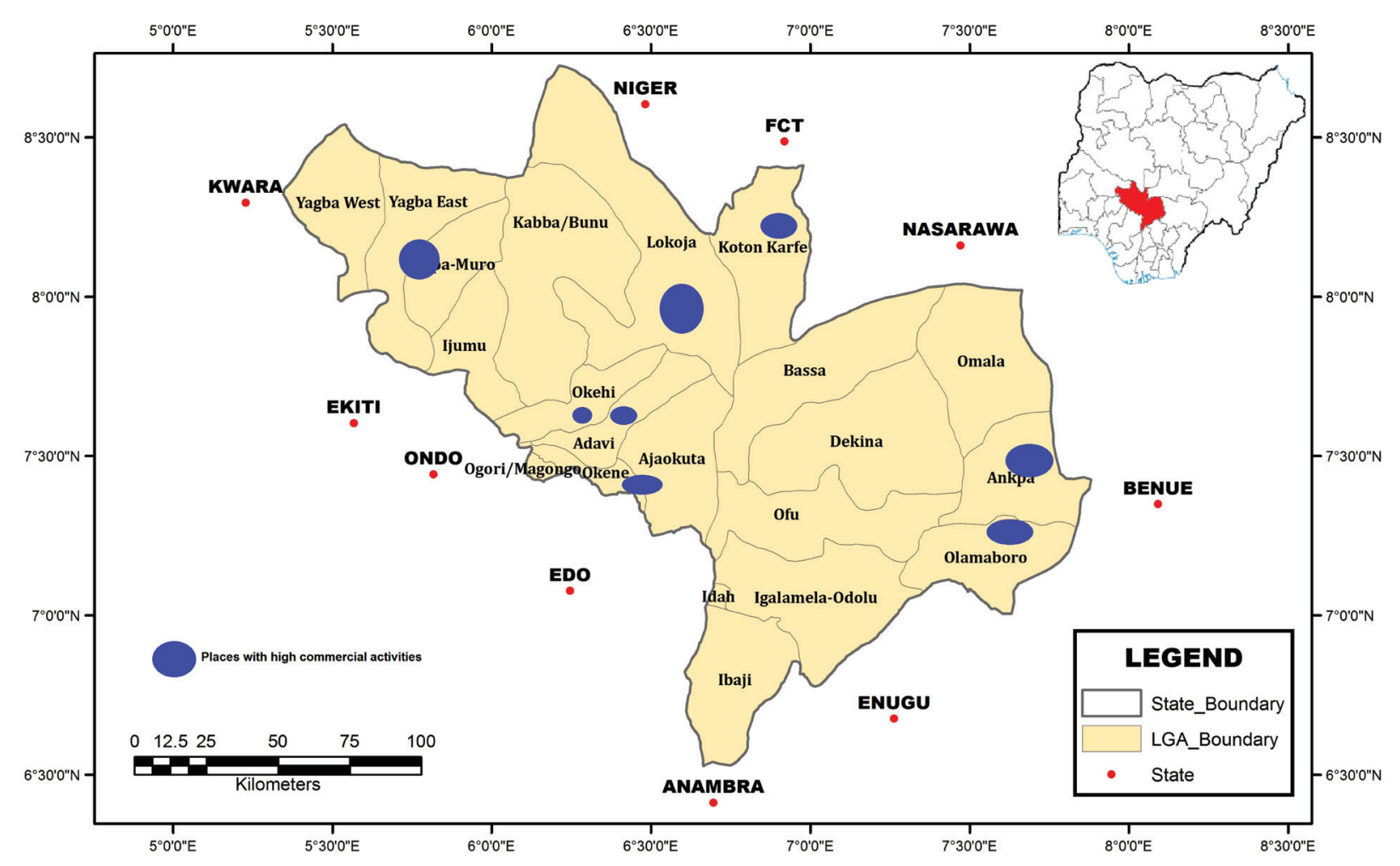

Fig. 1. Map of Kogi State showing the Local Government Area (LGA) and the state boundaries (insert: Nigeria Map showing the location of Kogi State) (after Fatoye \& Gideon 2014) 


\section{GENERAL GEOLOGY OF KOGI STATE}

The geological setting of Kogi State is unique in view of the occurrence of the two major components of the geology of Nigeria: the Basement Complex and Sedimentary Basin (Fig. 2). Approximately half of the state is covered by the crystalline Basement Complex (undifferentiated metasediment and older granite), while the other half is covered by Cretaceous to recent sediments. The Basement Complex predominantly underlies the western flank of the state. They are made up of undifferentiated meta-sediment and the Pan-African
Older Granites (KSMSMD 2004). The eastern flank lies partially within the sedimentary basin (Anambra basin), which includes major rock types such as sandstones, coal, limestone, shale, clay, mudstone and alluvium, with the sandstone being mainly of faslebedded sandstones. It chiefly comprises the different formations of Nkporo, Mamu, Ajali and Nsukka (Fatoye \& Gideon 2014). These formations are inter-bedded with sandstones, siltstones, carboniferous-shale, coal, sandstones of fluvial marine nature with distinct across beddings and laterite. The average magnetic susceptibility of rocks and sediments within the study area varies between $80-250 \times 10^{-5}$ SI (Obiora et al. 2016).

\section{DESCRIPTION}

\begin{tabular}{|c|}
\hline Alluvium \\
\hline Clays, sandstone and shale \\
\hline Coal, sandstone and shale \\
\hline Falsebedded sandstones, coal and shale \\
\hline Felspathic sandstones and siltstone \\
\hline Older Granite \\
\hline Shale and limestone \\
\hline Shale and mudstones \\
\hline Undifferentiated basement complex with pebble beds \\
\hline Undiffentiated meta-sediments \\
\hline
\end{tabular}

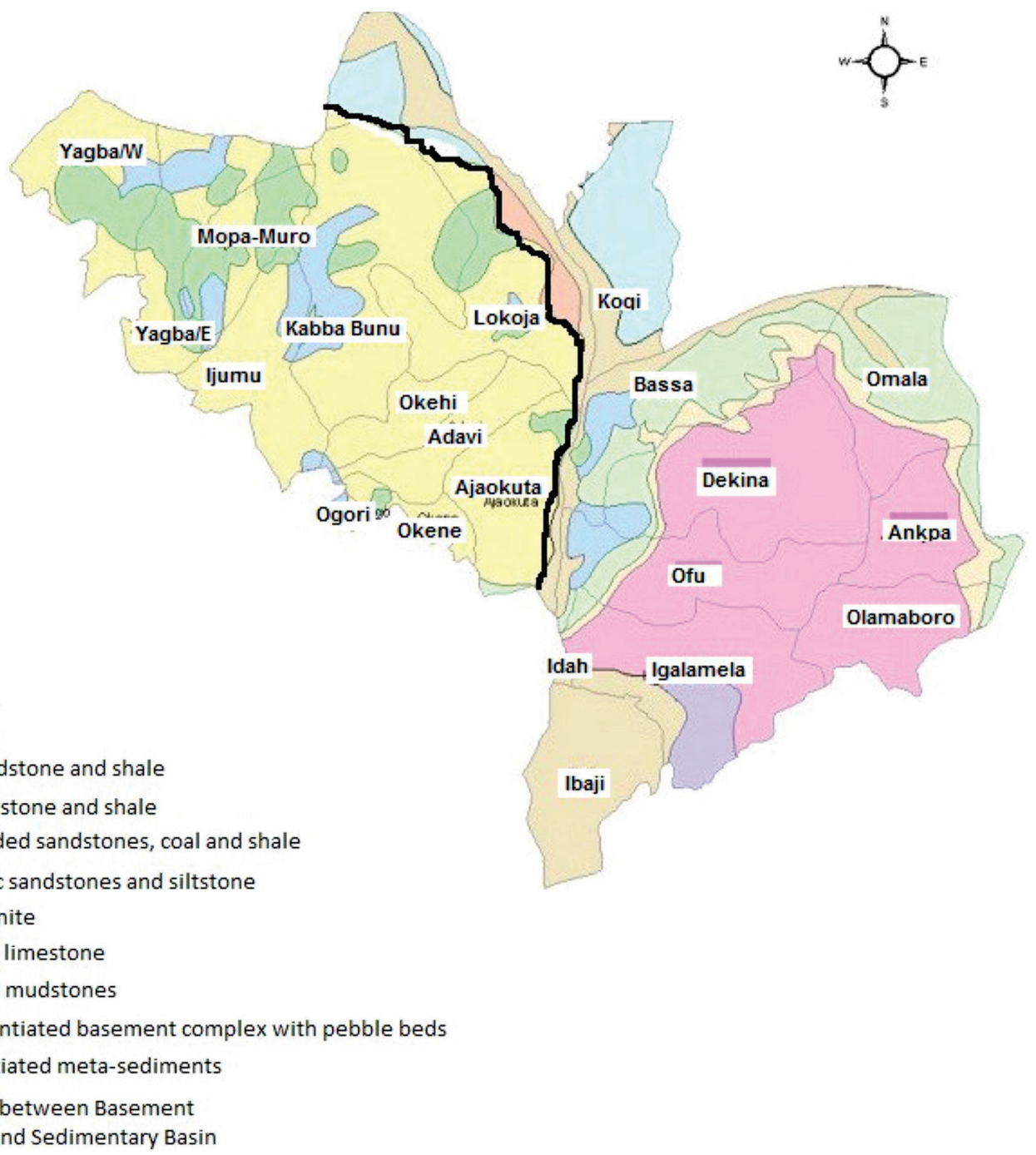

Fig. 2. Geological Map of Kogi State by the Local Government Area (after NGSA 2009) 


\section{SAMPLE COLLECTION AND METHODOLOGY}

The sampling strategy used in this study includes a combination of design features that have shown to work successfully in other studies (Sutherland \& Tolosa 2000, Banerjee 2003, Charlesworth et al. 2003, Gautam et al. 2005, Yin et al. 2005, Anagnostopoulou \& Day 2006, Booth et al. 2006, Haugland et al. 2007, Yang et al. 2010, Aidona et al. 2013). Samples were collected randomly from 220 locations (Fig. 3) (bearing in mind reasonable spacing). At each sampling point, an $80.0 \mathrm{~cm}$ hole was drilled using a $5.0 \mathrm{~cm}$ diameter stainless pipe. The samples were collected from the hole using a locally fabricated $4.0 \mathrm{~cm}$ diameter pipe with rotatable collectors at intervals of $10.0 \mathrm{~cm}$. The collected samples were homogenized and considered as one sample representative for the depth (e.g. 0-10 cm). In total, 1,760 samples were collected, dried, sieved to remove impurities, packed and labeled. The weight and magnetic susceptibility measurements were performed using a Bartington MS2B sensor in a uniform, low frequency magnetic field.

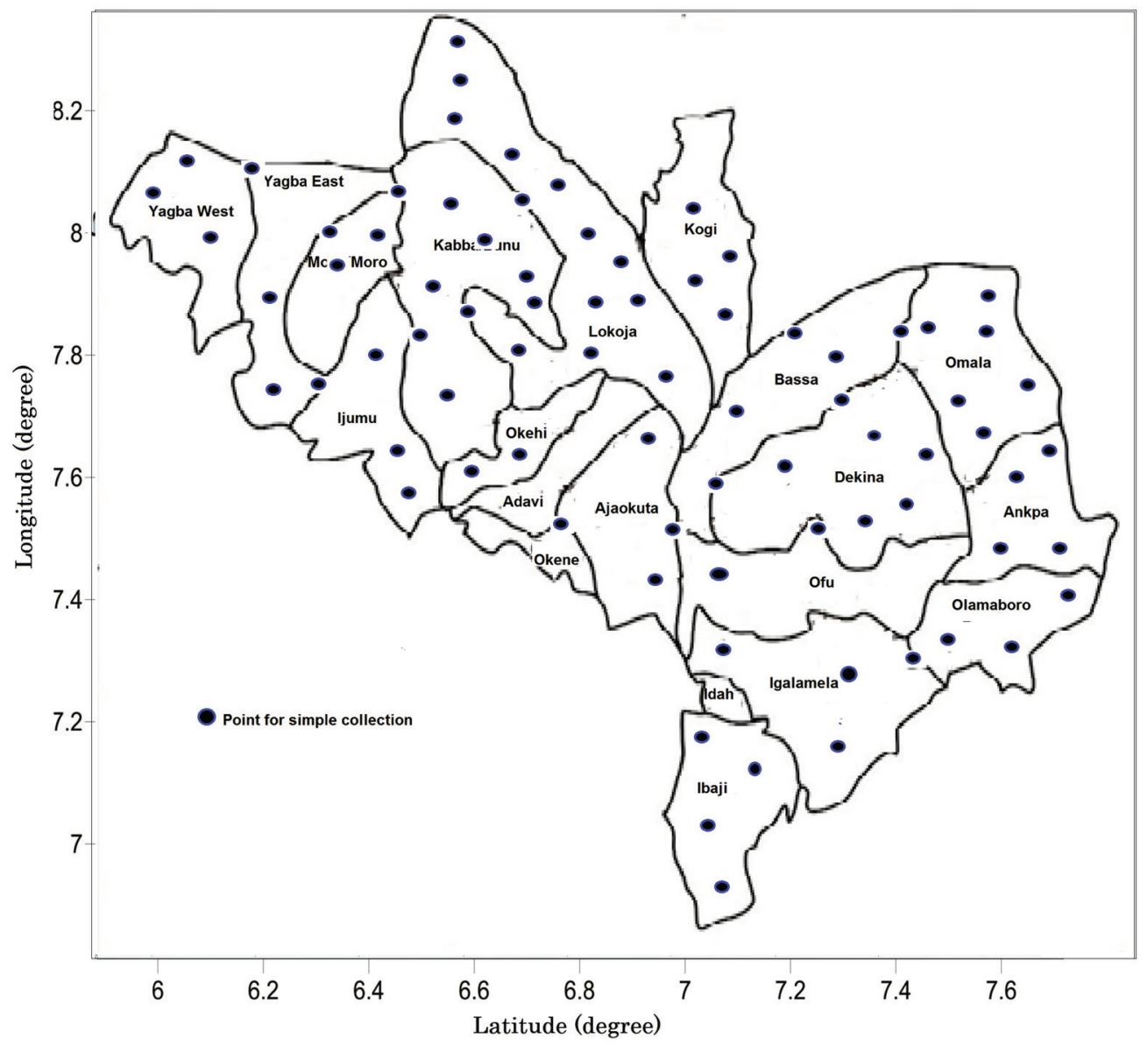

Fig. 3. Location of measurements carried out in Kogi State (points reduced for clarity)

\section{RESULTS AND DISCUSSION}

The spatial distribution map of magnetic susceptibility at different depths (e.g. $10 \mathrm{~cm}$ means samples from $0-10 \mathrm{~cm}$ interval) is shown in Figure 4 . The magnetic susceptibility varies between
$80-650 \times 10^{-5}$ SI. This wide variation in the soil susceptibility is mostly due to the processes that affect the soil's formation. These factors may include climate, parent materials, topography, and erosion, anthropogenic influences e.t.c. (Hanesch $\&$ Scholger 2005). 
A

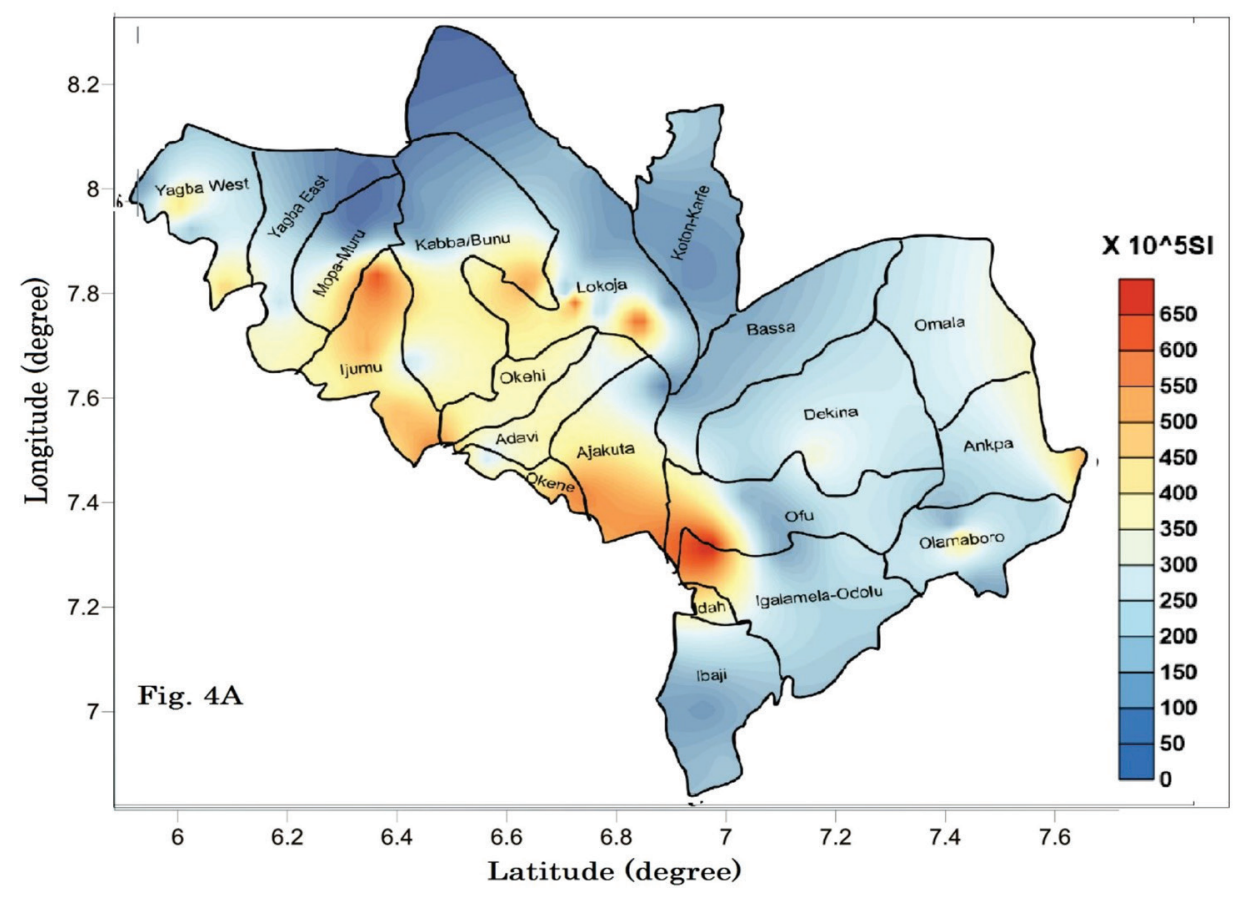

C

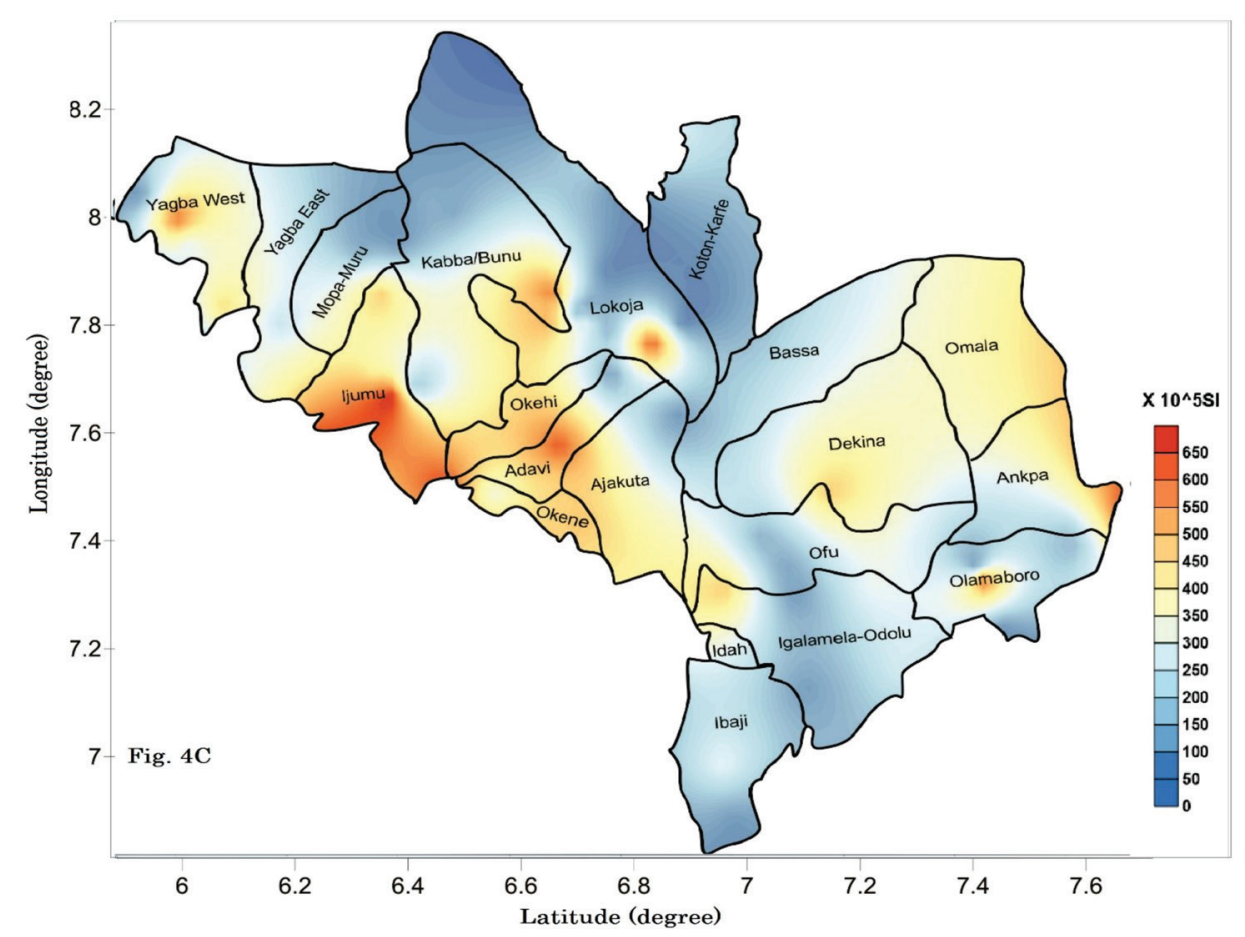

E

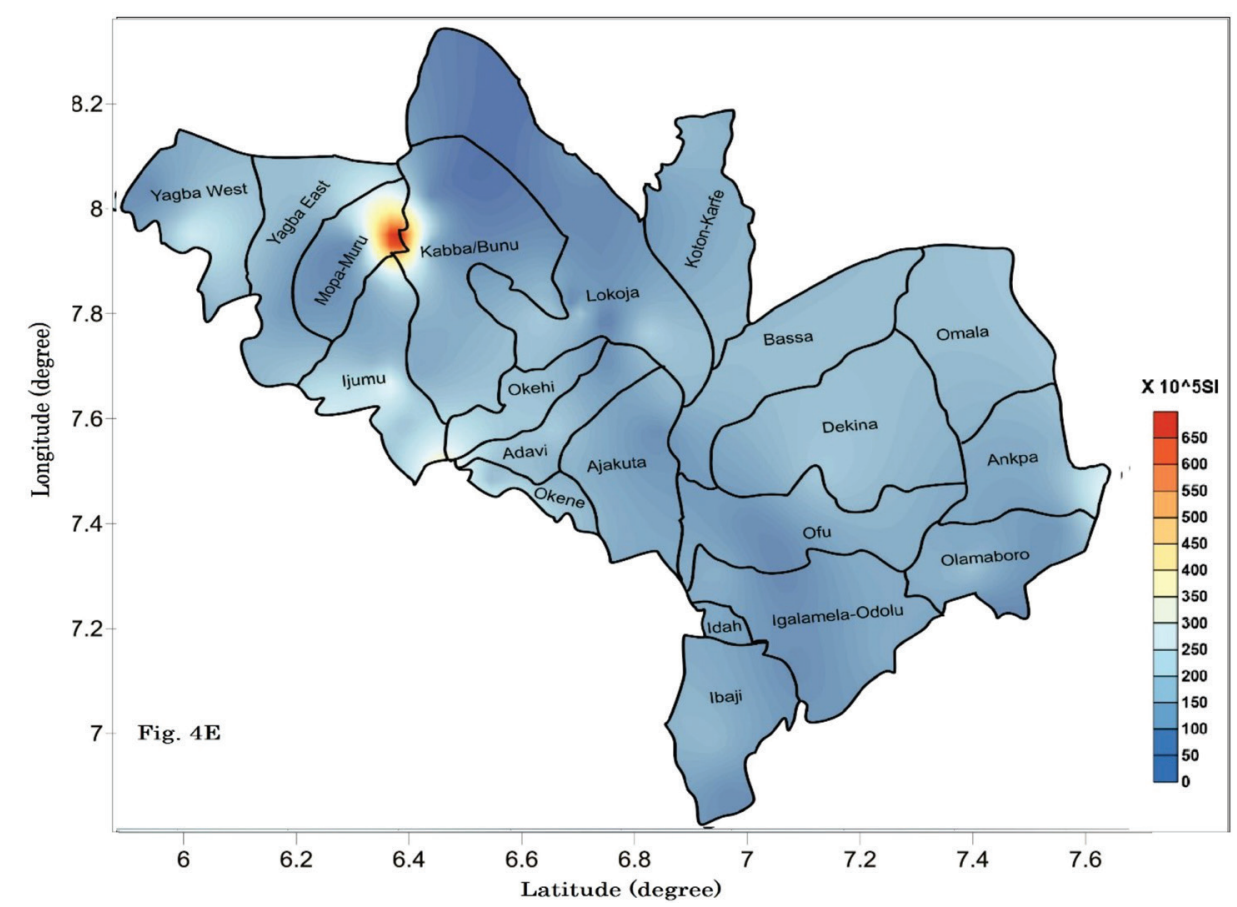

G

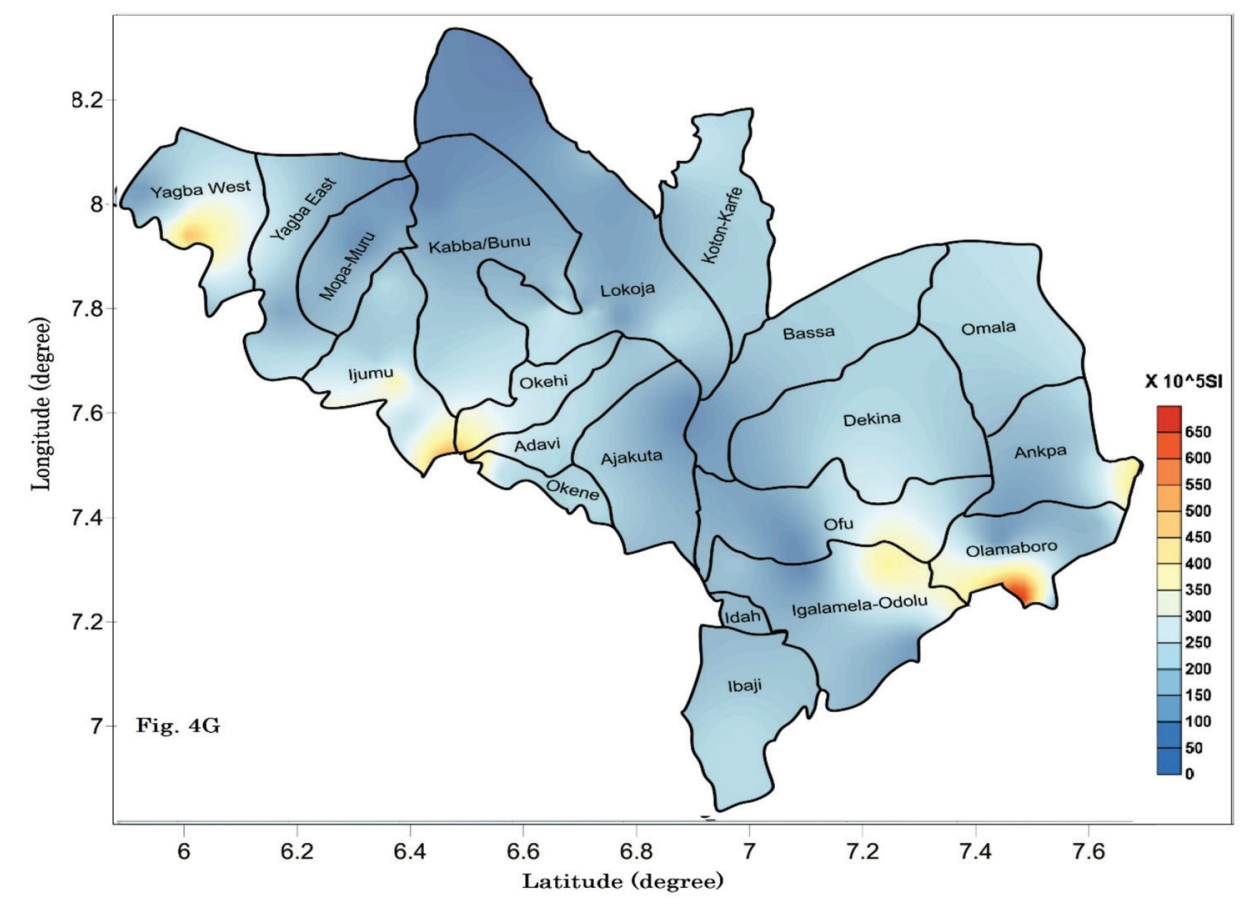

B

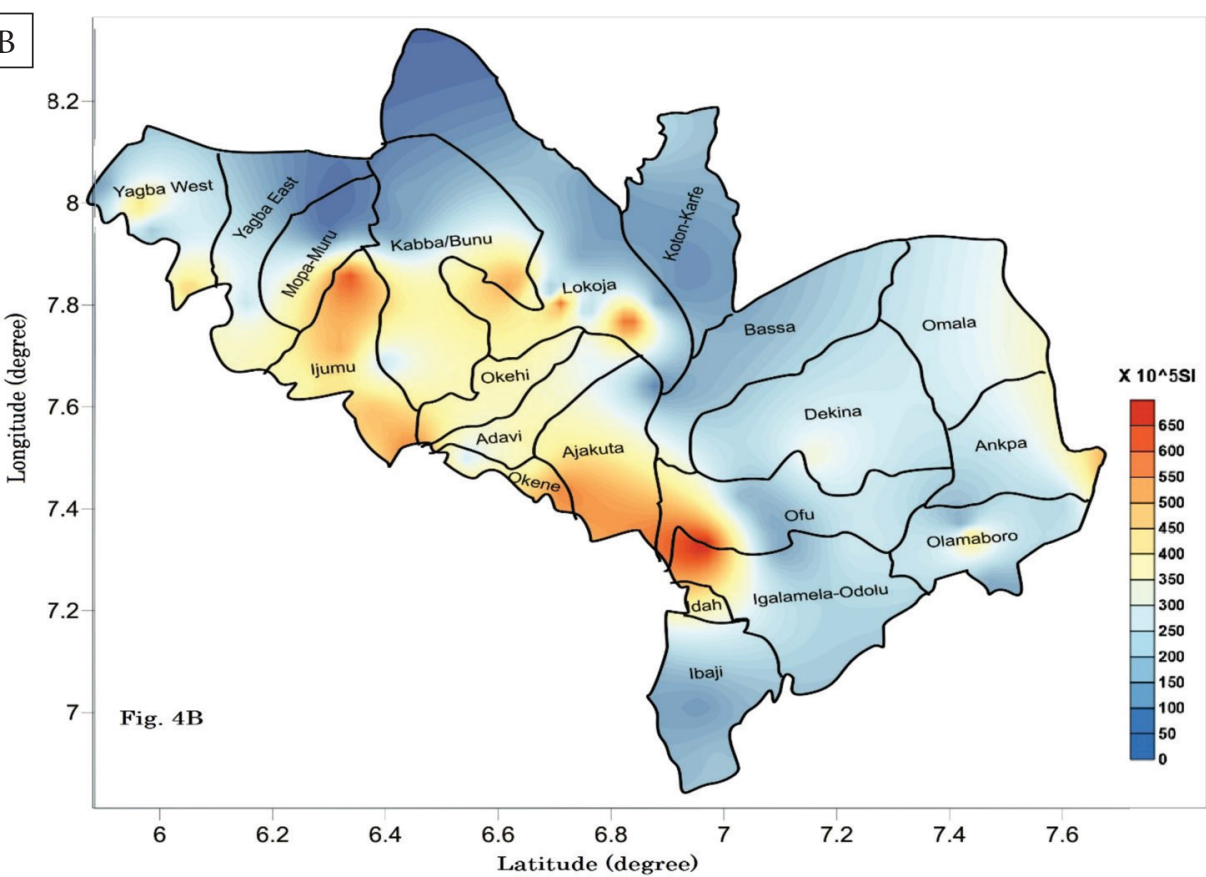

D
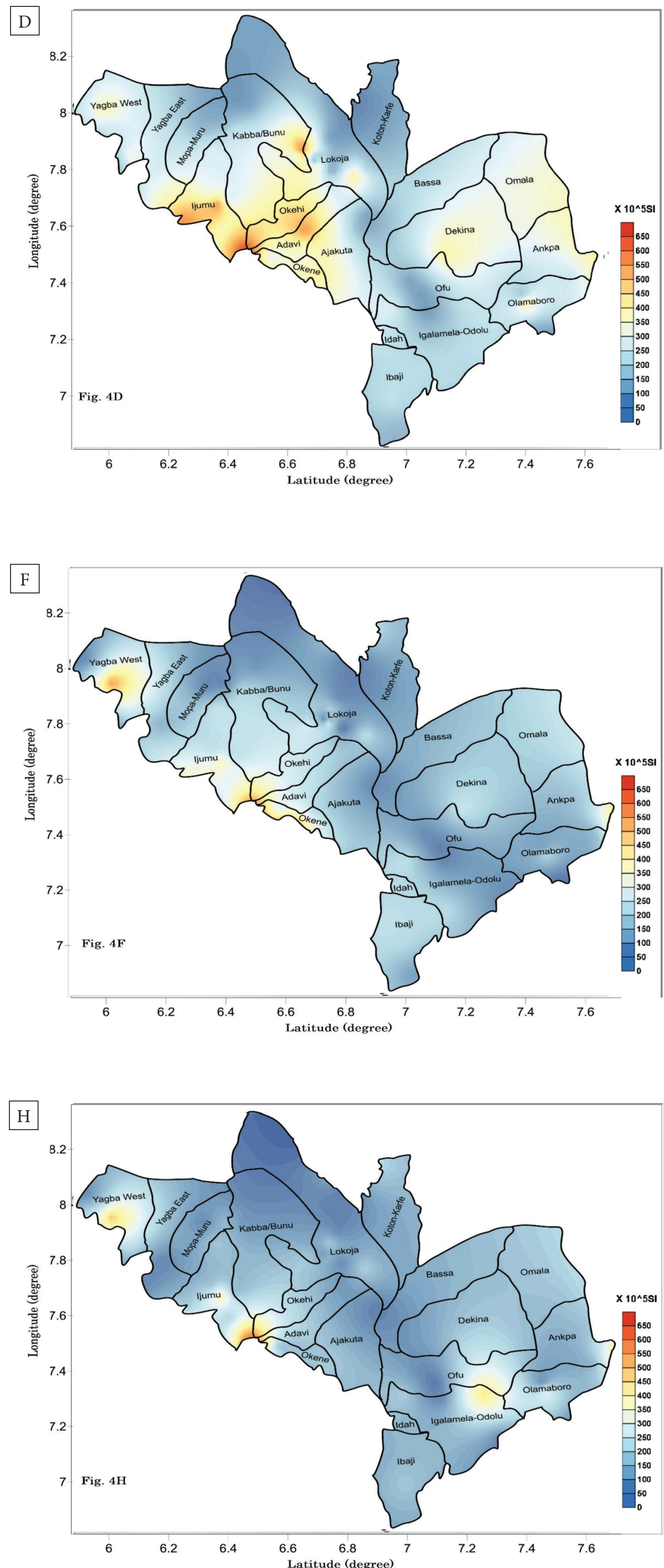
The enhancement of magnetic susceptibility in the soils was mostly observed from the surface soil to a depth of about $40.0 \mathrm{~cm}$, with values ranging between $300-650 \times 10^{-5} \mathrm{SI}$. From the spatial distribution maps, the enhancement of magnetic susceptibility is mostly concentrated in places like Okene, Lokoja, Ankpa and Omala, which are known to have high commercial activities. At the depth of $10 \mathrm{~cm}$ (Fig. 4A) the most enhanced values of about $400-600 \times 10^{-5} \mathrm{SI}$ are observed in two segments of the study area, with the Ijumu local government area having the highest values of $600-700 \times 10^{-5} \mathrm{SI}$. The two segments are separated by a region of low susceptibility, namely of about $100-350 \times 10^{-5} \mathrm{SI}$. The low susceptibility area coincides with the boundary of the basement complex rocks and the sedimentary basin of the study area (Obaje et al. 2011). Thus, a lower depth of magnetic susceptibility can be used to demarcate lithological units. In Figure $4 \mathrm{~B}$, the spatial map indicates a similar trend as at Figure $4 \mathrm{~A}$ in its western part, but it is observed that the eastern part of the study area, which happens to fall within the sedimentary basin, has a low susceptibility compared to other part of the state. At the depth of $50.0 \mathrm{~cm}$ (Fig. 4E), a highly enhanced magnetic susceptibility anomaly, with a value of about
$650 \times 10^{-5}$ SI, was observed at the boundary between Mopa and Kabba-Bunu local government areas. This maximum value is largely due to contamination from a buried metallic pipe observed during excavation within that portion, and no such levels were observed elsewhere. There is a general reduction of magnetic susceptibility with depth (Fig. 4E-H) with susceptibility reducing to about $50-200 \times 10^{-5} \mathrm{SI}$. This is evidence that enhancement of the top soil to a depth of about $40.0 \mathrm{~cm}$ may have arisen due to the deposition of anthropogenic dust magnetic minerals.

\section{Determination of the anthropogenic boundary through profiling}

The data used for the profiling was obtained from the digitization of the spatial distribution map of magnetic susceptibility at different depths (Fig. 4). The digitization method is based on interpolation using Surfer 13. This method involves drawing 3 straight profile lines (A, B and C) of about $250 \mathrm{~km}$ long, running in a NW-SE direction and separated at intervals of $50 \mathrm{~km}$ on each of the magnetic susceptibility distribution spatial maps (Fig. 5). Each of the profile is then digitized at intervals of $2 \mathrm{~km}$ and the digitized data is used to plot the $2 \mathrm{D}$ plots or depths against distance (Fig. 6).

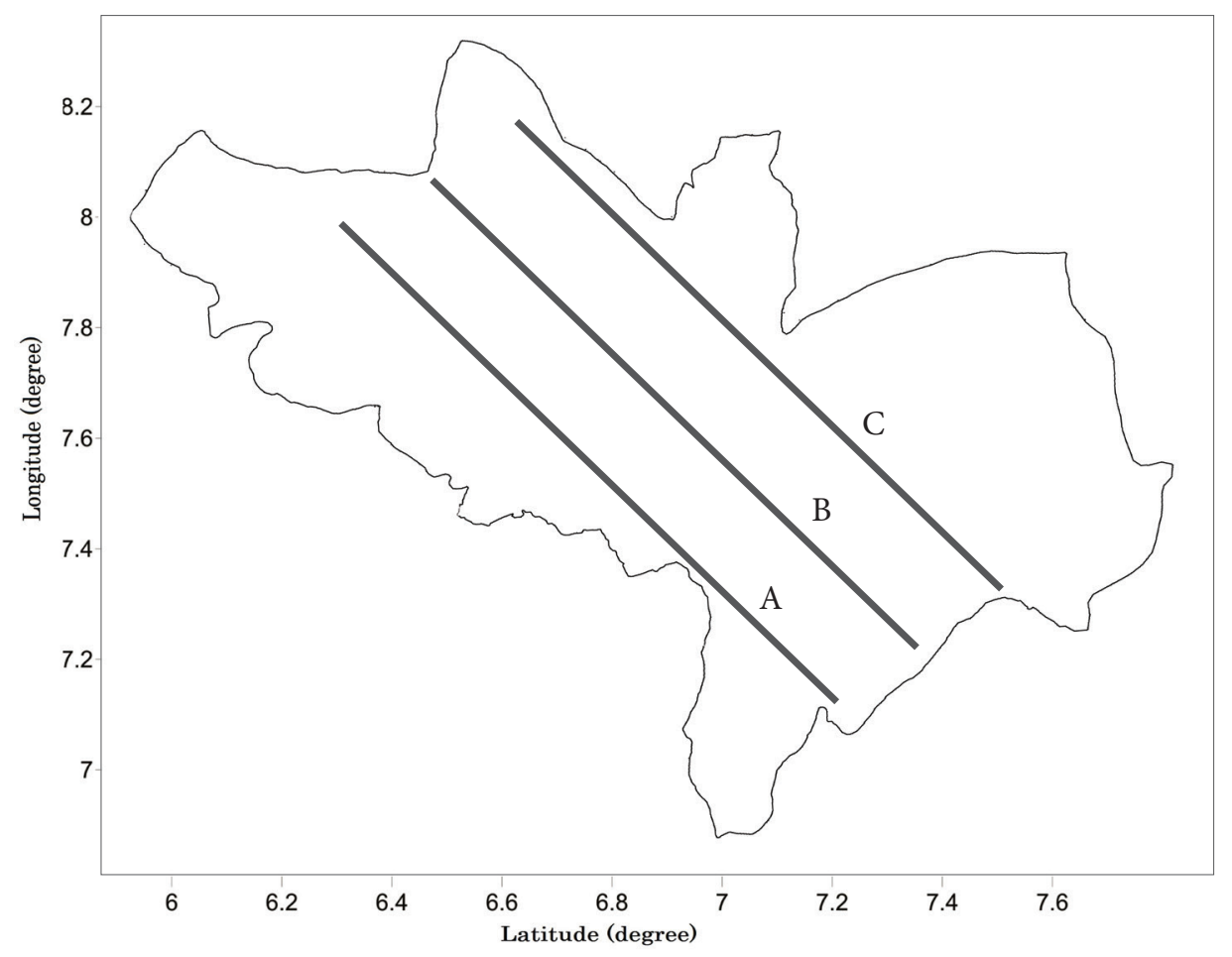

Fig. 5. Map of Kogi State showing the position of the profile lines insert legend 

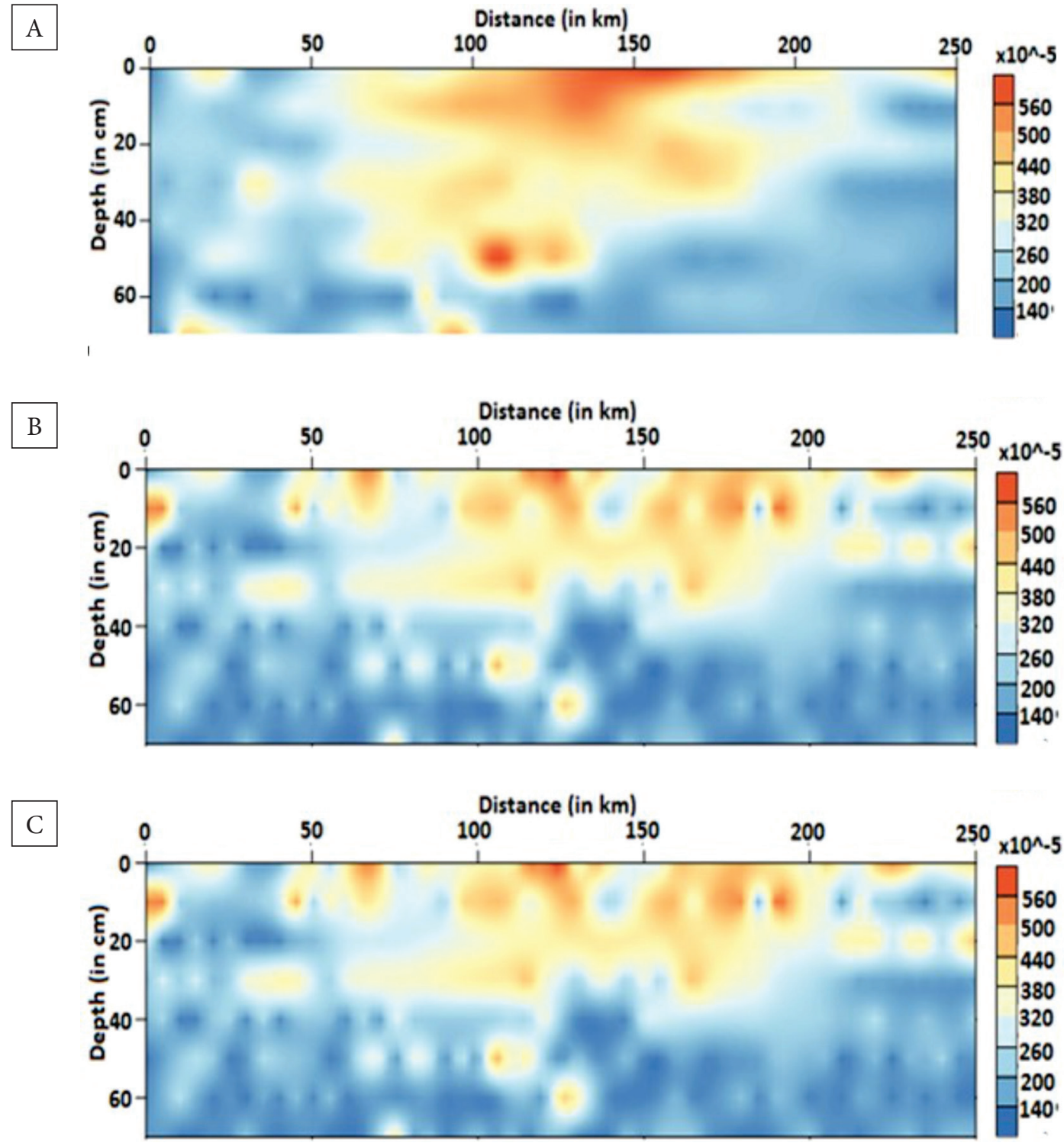

Fig. 6. $2 D$ diagram showing the distribution of magnetic susceptibility from the surface to a depth of $80.0 \mathrm{~cm}$ along: A) profile A; B) profile $B$; C) profile $C$

From the 2D profile plots (Fig. 6), it is clearly observed that there is no evidence of uniform layering in the profiles. This indicates that the enhancements are actually localized, and restricted to commercial areas as a result of anthropogenic activities (Petrovský et al. 2010). The anomalous magnetic susceptibility observed in Figure 4E, is clearly visible along profile $A$ at a depth of $50.0 \mathrm{~cm}$ (Fig. 6A). Beside this distinct feature at a depth of $50 \mathrm{~cm}$ in profile A, magnetic susceptibility shows slight decreases with depth. The boundary between anthropogenic and lithogenic influence can be said to fall within $40-50 \mathrm{~cm}$ in places, showing enhanced susceptibility in the top soil, and $20-30 \mathrm{~cm}$ in places with low susceptibility in the top soil.

\section{CONCLUSION}

The study area encompassed both the basement complex and sedimentary basin in nearly equal proportions. The spatial distribution of the magnetic susceptibility map successfully shows the boundary between the basement complex rocks and the sedimentary basin within the study area 
and also reveals that the enhancement of magnetic susceptibility reduces with depth. This is an indication that enhancement in the top $40 \mathrm{~cm}$ of the soil is due to the continual deposition of anthropogenic magnetic minerals. The non-layering of the $2 \mathrm{D}$ profiles plot is an indication that the enhancement observed at the maps are localized and restricted mostly to areas with high commercial activities like marketplaces, or the Obajana cement factory etc. The boundary between anthropogenic and lithogenic influence is between $40-50 \mathrm{~cm}$ in areas with high commercial activities and $20-30 \mathrm{~cm}$ in areas with fewer commercial activities.

\section{REFERENCES}

Anagnostopoulou M.A. \& Day J.P., 2006. Lead concentrations and isotope ratios in street dust in major cities in Greece in relation to the use of lead in petrol. Science of the Total Environment, 367(2-3), 791-799.

Banerjee A.D.K., 2003. Heavy metal levels and solid phase speciation in street dusts of Delhi, India. Environmental Pollution, 123(1), 95-105.

Booth C.A., Shilton V., Fullen M.A., Walden J., Worsley A.T. \& Power A.L., 2006. Environmental magnetism: measuring, monitoring and modelling urban street dust pollution. [in:] Longhurst J.W.S. \& Brebbia C.A. (eds.), Air Pollution XIV, Wessex Institute of Technology (WIT) Press, Southampton, 333-342.

Boyko T., Scholger R. \& Stanjek H., 2004. Topsoil magnetic susceptibility mapping as a tool for pollution monitoring: repeatability of in situ measurements. Journal of Applied Geophysics, 55, 249-259.

Chaparro M.A.E., Gogorza C.S.G., Irurzun M.A. \& Sinito A.M., 2006. Review of magnetism and heavy metal pollution studies of various environments in Argentina. Earth Planets Space, 58(10), 1411-1422.

Charlesworth S., Everett M., McCarthy R., Ordonez A. \& De Miguel E.A., 2003. Comparative study of heavy metal concentration and distribution in deposited street dusts in a large and a small urban area: Birmingham and Coventry, West Midlands, UK. Environmental International, 29, 563-573.

Dearing J.A., Hay K., Baban S., Huddleston A.S., Wellington E.M.H. \& Loveland P.J., 1996. Magnetic susceptibility of topsoils: a test of conflicting theories using a national database. Geophysical Journal International, 127, 728-734.

D’Emilio M., Chianese D., Coppola R., Macchiato M. \& Ragosta M., 2007. Magnetic susceptibility measurements as proxy method to monitor soil pollution: development of experimental protocols for field surveys. Environmental Monitoring and Assessment, 125, 137-146, https://doi. org/10.1007/s10661-006-9246-1.

Fatoye F.B. \& Gideon N.D., 2014. Geology and mineral resources of the Lower Benue Trough, Nigeria. Advances in Applied Science Research Journal, 4(6), 21-28.
Gautam P., Blaha U. \& Appel E., 2005. Magnetic susceptibility of dust-loaded leaves as a proxy of traffic-related heavy metal pollution in Kathmandu City, Nepal. Atmospheric Environment, 39(12), 2201-2211.

Georgeaud V.M., Rochette P., Ambrosi J.P., Vandamme D. \& Williamson D., 1997. Relationship between heavy metals and magnetic properties in a large polluted catchment: the Etang de Berre (South of France). Physics and Chemistry of the Earth, 22(1-2), 211-214.

Hanesch M \& Scholger R., 2005. The Influence of soil type on the magnetic susceptibility measured throughout soil profiles. Geophysical Journal International, 161(1), $50-56$.

Haugland T., Ottesen R.T. \& Volde T., 2007. Lead and polycyclic aromatic hydrocarbons (PAHs) in surface soil from day care centres in the city of Bergen, Norway. Environmental Pollution, 153(2), 266-272.

Jatto S.S., Peter O.S. \& Ahmed A.L., 2016. 3-dimensional surface magnetic susceptibility distribution with depth to investigate anthropogenic pollutants boundary in Abuja Metropolis. Geology, Geophysics and Environment, 42(4), 443-448.

Jordanova N., Jordanova D. \& Tsacheva T., 2008. Application of magnetometry for delineation of anthropogenic pollution in areas covered by various soil types. Geoder$m a, 144(3-4), 557-571$.

Kanu M.O., Meludu O.C. \& Oniku S.A., 2013. A preliminary assessment of soil pollution in some parts of Jalingo Metropolis, Nigeria using magnetic susceptibility method. The Jordan Journal of Earth and Environmental Sciences, 5(2), 53-61.

Kapička A., Petrovský E., Jordanova N. \& Podrázský V., 2001. Magnetic properties of forest top soils in Krkonose Mountains, Czech Republic. Physics and Chemistry of the Earth, Part A: Solid Earth and Geodesy, 26, 917-922.

Kim W., Doh S.J., Park Y.H. \& Yun S.T., 2007. Two-year magnetic monitoring in conjunction with geochemical and electron microscopic data of roadside dust in Seoul, Korea. Atmospheric Environment, 41, 7627-7641.

Knab M., Appel E. \& Hoffmann V., 2001. Separation of the anthropogenic portion of heavy metal contents along a highway by means of magnetic susceptibility and fuzzy c-means cluster analysis. European Journal of Environmental Engineering and Geophysics, 6, 125-140.

KSMSMD, 2004. Guide to Investment Opportunities in the Solid Minerals Sector of Kogi State. Kogi State Ministry of Solid Minerals Development.

Lu S. \& Bai S., 2008. Magnetic characterization and magnetic mineralogy of the Hangzhou urban soils and its environmental implications. Chinese Journal of Geophysics, 51(3), 549-557.

Magiera T., Stryszcz Z., Kapička A. \& Petrovský E., 2006. Discrimination of lithogenic and anthropogenic influences on topsoil magnetic susceptibility in Central Europe. Geoderma, 130, 299-311.

NGSA, 2009. Geological Map of Kogi State. Nigerian Geological Survey Agency.

Obaje N.G., Moumouni A., Goki N.G. \& Chaanda M S., 2011. Stratigraphy, paleogeography and hydrocarbon resource potentials of the Bida Basin in North-Central Nigeria. Journal of Mining and Geology, 47(2), 97-114. 
Obiora D.N., Yakubu J.A. \& Okeke F.N., 2016. Interpretation of aeromagnetic data of Idah area in North Central, Nigeria using combined methods. Journal of Geology Society, India, 88, 98-106, https://doi.org/10.1007/s12594016-0462-1.

Petrovský E. \& Ellwood B.B., 1999. Magnetic monitoring of pollution of air, land and waters. [in:] Maher B.A. \& Thompson R. (eds.), Quaternary Climates, Environments and Magnetism, Cambridge University Press, Cambridge, 279-322.

Petrovský E., Hulka Z. \& Kapička A., 2010. A new tool for in situ measurements of the vertical distribution of magnetic susceptibility in soils as basis for mapping deposited dust. Journal of Environmental Technology, 25(9), 1021-1029.

Sarris A., Kokkinou E., Aidona E., Kallithrakas-Kontos N., Koulouridakis P., Droulia K. \& Damianovits O., 2009. Environmental study for pollution in the area of Megalopolis power plant in the wide area of the power plant of Megalopolis (Peloponnesus, Greece). Environmental Geology, 58, 1769-1783.
Sutherland R.A. \& Tolosa C.A., 2000. Multi-element analysis of road-deposited sediment in an urban drainage basin, Honolulu, Hawaii. Environmental Pollution, 110(3), 483-495.

Yang T., Liu Q., Li H., Zeng Q. \& Chan L., 2010. Anthropogenic magnetic particles and heavy metals in the road dust: magnetic identification and its implications. Atmospheric Environment, 44(9), 1175-1185.

Yin J., Allen A.G., Harrison R.M., Jennings S.G., Wright E., Fitzpatrick M., Healy T., Barry E., Ceburnis D. \& McCusker D., 2005. Major component composition of urban PM10 and PM2.5 in Ireland. Atmospheric Research, 78(3-4), 149-165.

Zananiri I., Kondopoulou D. \& Spassov S., 2010. The application of environmental magnetism techniques for pollution assessment in urban and suburban areas of Greece: state of the art and case studies. Bulletin of the Geological Society of Greece, 43(4), 1972-1982.

Zawadzki J., Magiera T., Fabijańczyk P. \& Kusza G., 2012. Geostatistical 3-dimensional integration of measurements of soil magnetic susceptibility. Environmental Monitoring and Assessment, 184(5), 3267-3278. 